\title{
CONTEMPORARY CHANGES IN THE HOTEL PRODUCT FOR SPA AND WELLNESS TOURISM AND THEIR DISTRIBUTION
}

\section{САВРЕМЕНЕ ПРОМЕНЕ У ХОТЕЛСКОМ ПРОИЗВОДУ ЗА СПА И ВЕЛНЕС ТУРИЗАМ И ЊИХОВА ДИСТРИБУЦИЈА}

\author{
Snejinka Kadieva ${ }^{1}$
}

College of Tourism, University of Economics, Varna, Bulgaria

\begin{abstract}
The paper focuses on modern changing trends of hotel product for spa and wellness tourism based on successful international experiences. Opportunities for applying such practices in Bulgaria are outlined, aiming at providing the Bulgarian spa and wellness hotel product with competitive advantages. The objective of this paper is to identify specific distribution channels for the specializes hotel product, directed at tourists with motivation of buying spa and wellness holidays, thus attracting a greater tourist flow to Bulgaria.
\end{abstract}

Key words: spa \& wellness tourism industry trends, contemporary changes of spa \& wellness hotel product, spa \& wellness hotel product distribution

Резиме: Рад се фокусира на савремене трендове промена хотелског производа за спа и велнес туризам заснованог на успешним међународним праксама. Наведене су могућности за примену такве праксе у Бугарској, с ииљем пружања конкурентских предности бугарском спа и велнес хотелском производу. Циљ овог рада је да се идентификују специфични канали дистрибуиије за специфични хотелски производ, који би били усмерени на туристе са мотивачијом конзумирања спа и велнес одмора, како би се на тај начин привукао већи број туриста у Бугарској.

\footnotetext{
${ }^{1}$ snejinakadieva@gmail.com
} 
Кључне речи: спа и велнес трендови туристичке привреде, спа и велнес савремене промене, дистрибуииј спа и велнес хотелског производа.

\section{INTRODUCTION}

The fast development of spa and wellness tourism has established as an international trend, which is determined by the desire of modern tourists to look and feel better, slow down aging processes, reduce their weight, relieve pains or discomfort, deal with stress and improve their physical and psychological state (Berg, 2008). The greater demand for spa and wellness services has lead to redirecting investment towards the spa and wellness industry in the resorts areas as well as the residential areas where consumers live. The number of tourism trips and tourist expenditure on wellness products is growing.

The Global Wellness Tourism Report data revealed in 2013, prepared by the Global Wellness Institute (GWI) and the Stanford Research Institute (SRI), prove the following trends (The Global Wellness Tourism Economy, 2013):

- Wellness tourism accounts for about $6 \%$ of all domestic and inbound tourism trips - 524400000 trips;

- Tourist expenditure on wellness tourism is around 14\% (438 600 billion US dollars) of all tourism services expenditure;

- $9 \%$ projected annual growth of wellness tourism by 2017 , i.e. $50 \%$ faster rate than global tourism in general;

- A substantial amount of total expenditure (438, 6 billion US dollars) concerning consumption of wellness tourism products is on accommodation during the trip - 93,4 billion US dollars; 71,9 billion US dollars on food and drink, whereas 61,4 billion US dollars are spent on spa and wellness packages and services, fitness, meditation, special interest trips, etc.;

- Tourists for whom wellness tourism is the main motivation factor for taking a trip comprise a small market segment. They account for $13 \%$ of consumers, but they tend to spend more - on average 2066 US \$ per tourism trip;

- Tourists for whom wellness is just a secondary (supporting) motive on a tourism trip are the larger segment (87\%), but they spend on average 680 US \$ per tourism trip;

- On the whole, the international/inbound wellness tourist's expenditure rate is $65 \%$ more than the average international/inbound tourist;

- The domestic spa tourist spends $150 \%$ more than the average domestic tourist; 
- Wellness tourism achieves good synergy with other kinds of specialinterest tourism, which also experience growth, eco, cultural, sports, rural tourism, etc.

The hotel spa and wellness product determines, to a great extent, the complete product for wellness tourism, for the fact that in most cases wellness and spa centers are part of the hotel super and infrastructure. Hotels can be either specialized spa hotels or standard hotels with a spa centre, as an addition to the whole hotel product. We should also mention here that there are special spa centre facilities built outside hotel premises in a number of health resorts, they are used both by tourists resident in the hotel and local people from the public. In other cases hotel spa and wellness centres are used by non-resident locals because there are no such facilities in their residential area.

In the last decade the hotel spa and wellness product has been undergoing a lot of changes in order to meet the rising demands of tourists in pursuit of maintaining healthy living and enhancing their physical and mental wellbeing.

I shall outline the main trends exhibited on the international market of wellness and spa tourism which predetermine the changes of content and vision of the modern hotel product.

First, I will point out that the age range of spa tourism clientele is getting wider. Today people traveling for spa and wellness tourism purposes are not only those of the third age, wishing to cure chronic diseases and recover after a medical condition, but also young people at an active working age, wishing to maintain their good health and ability for active work through prevention, prophylaxis and generally practicing a healthier lifestyle. "Predictions are of a future trend of spa programs targeted at a wider range of people, offering group packages will be of greater importance: practicing spa from the age of 6 to a 106. The spa industry is constantly diversifying its offering, making it accessible to people of any age. The best spa services for children, their parents and elderly people. They could have a holiday together, relax, relieve pressure and stress, while family relationships are strengthened" (Sacharinov, Rizova, 2011, p.216-217).

Second: The relative market share of men going for spa is increasing. Although women traveling for spa and wellness tourism purposes are still the predominant market, the relative share of men is clearly rising. They tend to use spa therapies more and more, as well as wellness programs, including fitness, body building, shaping, etc. 
Among the motivation for taking medical, spa and wellness tourism trips the following trends can be identified: a desire to escape from the routine of everyday life and pressure; the desire to slow down the constant competition with time and the dynamic lifestyle, attaining an extent of solitude and relaxation; communicating with people with a similar attitude to life, where not only material values matter, but the emphasis is on the spiritual; a desire for self-improvement and reaching the perfect balance between spirit, body and soul; keeping to a healthy diet by consuming more natural products and foods gown and eaten locally.

In accordance with the changes in the range of values and motivation of today's tourists there has been a new variety of hotel offers and their combination with services and therapies catering for physical as well as mental and spiritual health, applying alternative curative methods, holistic medicine, creating an environment even more conducive to pleasure, relaxation and positive emotions.

A new trend has to be noted - introducing spa packages within incentive travel programs, business travel, in addition to fringe programs of conference events, seminars and other business conventions. There has been an increase in cruise trips themed around "spa and wellness". When building hotel super and infrastructure more emphasis has been put on environmentally friendly architecture, energy-saving facilities and systems, the use of natural material in spa centers, such as leather, stone, wood, architectural designs matching the natural landscape, etc.

There has been a steady trend of developing an eco-friendly spa and wellness hotel product, including the construction of hotel complexes meeting all criteria of low impact on the environment and achieving harmony with it. This often includes the introduction of alternative methods for cure and maintaining physical well-being, of recreation, recuperation and rejuvenation therapies using local resources, as well as treatments, even food diets focusing on the use of natural products involving minimum, even zero consumption of electricity and chemical substances.

The hotel spa and wellness product is closely associated with the spa destination product. This leads to a new trend of hotel offers reflecting the local identity of the destination, unique natural resources, mineral waters, curative mud, climate, etc., as well as providing new benefits and experiences for holidaymakers communing with the local environment and culture. Spa and wellness centers have increasingly been offering educational programs promoting healthy way of living, health prevention, fitness programs, healthy diets, detoxification, etc. Another trend in the offers of modern hotel spa and wellness centers is programs featuring exotic rituals and ceremonies, as well 
as extensively introducing eastern methods for cure - Chinese, Japanese, Indian, etc. According to a number of surveys, massage has remained the most popular service in all its varieties (Rafailova, Kadieva, et al., 2012).

Spa and wellness centers have become focal points for socializing, what they used to be even at the start of their existence in antiquity. The hotel product concept has been targeted at the spa and wellness market segments. There has been a process of branding and rebranding of the hotel product, focusing on the "health, spa and wellness" theme (Spafinder Wellness, Inc., 2014.). A good example of this can be given by the hotel consortium "Healing Hotels of the World". Hotel products such as "casino \& spa hotels", "golf \& spa hotels", ""sport \& spa hotels".

The modern spa and wellness hotel product aims at achieving product unity in all its elements, i.e. not only state-of-the-art facilities of the spa and wellness centers within the hotels and the spa receptionists available, but also modern furnishings in the hotel rooms, like fitness equipment, jacuzzi baths, spa showers, sound systems reproducing "sounds of nature" (the EVEN Hotels chain within the Intercontinental Hotel Group). Restaurants have started offering organic, vegan and gluten-free menus (the Trump Wellness Hotels chain), appointing special concierges ready to give guests advice and information on the spa and wellness packages, spa programs, rentals of sports equipment and facilities, etc.

Distribution of the spa and wellness hotel product has been increasingly carried out by specialized tour operators, as well as established and wellknown tour operators, who include spa end wellness trips and holiday packages in their product port-folio, and also publish specialized brochures and catalogues. Such companies are: Ameropa Wellnessreisen, DERTOUR /Dr.Holiday-Gesundheit \& Reisen. Euromed "Kur \&Vital", FIT Reisen - Kur\&Wellness-Oasenweltweit, Kur Club Franz Rais, NeckermannReisen "Neckermann Care", Thomas Cook Reisen - "Wellness\&Mehr" and others.

A new trend has been consistent, that of introducing standards of quality in medical and spa centres and hotels through voluntary certification and meeting internationally recognized standards. The most prestigious in Europe are the two certificates of the European Spa Association - "Europaspa med", with more than 400 quality indicators and "Europaspawellness", with 350 indicators respectively. The facilities and features of hotels subject to audit in order to be awarded those quality certificates are related mainly with the specialized facilities and equipment, safety, hygiene, infrastructure, staff qualification and quality of service. Appendix №1, enclosed within the paper, outlines the organizations and associations in Europe, mainly Germanspeaking countries, which have established their voluntary certification 
systems for spa and wellness products according to which a number of wellknown spa and wellness hotels in Europe have been certified.

Over the last decade substantial investments have been made in the field of spa and wellness tourism in Bulgaria. According to statistics given by the President of the Bulgarian Union of Balneology and Spa Tourism, Stefan Sharlopov, over 1 billion Euros have been invested in the spa and wellness industry in Bulgaria for the last ten years (Investiror.BG, 2014). A number of specilized balneo-spa and wellness hotels, have been constructed as well as many hotels with spa centres as an additional element to the hotel product have appeared. Among the most notable ones are:

- Five-Star Hotels: Spa Hotel "The Palace" - Velingrad, Spa Hotel "Rich", Hotel "Kempinski Grand Arena" - Bansko, Park Hotel "Pirin" - Sandanski, Spa Hotel "Sveti Nikola" - in the town of Sandanski, Hotel "Strymon Spa Club"- Kyustendil, Spa Hotel "Persenk" - Devin, Grand Hotel "Pomorie"- Pomorie, Hotel "Emerald" - Ravda , Hotel "Melia Grand Hermitage" - Golden Sands and others.

- Four-Star Hotels: Spa Hotel "Bor" - Velingrad, Spa Hotel "Devin" Devin, Spa Hotel "Eurydice" - Devin, Spa Hotel "Media " in the town of Sandanski, Spa Hotel "Yastrebetz " - in the resort of Borovets, Spa Hotel "Sandanski" - Sandanski, Belchin Garden Spa Hotel - Samokov, Riu Pravets Golf \& Spa Sana Spa Hotel - Hissar Spa Hotel "Hissar" - in the town of Hissar, Spa Hotel "Seuthopolis" Pavel Banya, Spa - Complex "Laguna Beach" - Sozopol, Spa Hotel "Romance" - "St. Constantine and Elena" resort ,"Orchid Boutique Spa Hotel" Golden Sands and others, Spa Hotel "Saint George" Pomorie.

- The first Chain of Spa Centres has been established, named "Victoria spa", which are located in the following hotels, Hotel "Dedeman - Princess" - Sofia, Hotel "RIU Pravets - Golf and Spa", "Grand Monastery" Complex - Pamporovo, "The Arena" Complex St. Vlas, Hotel "Via Pontic"- Pomorie. The chain successfully manages the spa centres and conducts spa training courses, offering graduates work and career within the chain.

Bulgaria has witnessed the establishment of a number of non-government associations in the field of spa and wellness tourism, whose aim is to combine the efforts of all stakeholders taking active part in its development and help implement efficient policies set out by the government, municipalities and the industry.

At present the major problems regarding the spa and wellness hotel product in Bulgaria are introducing standards and certification procedures of the spa 
and wellness facilities available. The health (medical) centers functioning within the balneo-hotels are constructed and work complying with the Law of Medical Establishments in the Republic of Bulgaria. Balneo-Spa and Wellness Hotels fall within the Bulgarian Regulations for Categorization of Accommodation and Catering and Entertainment Establishments. Chapter nine of the current Tourism Law, having come into force in 2013, defines the conditions and rules by which spa and wellness services are to be offered and the certification procedures of balneo, spa and wellness and thalasso-therapy centres. The additional regulations to the Law define the characteristics of balneo-spa and wellness and thalasso-therapy centres.

However, Certification Regulations, which have to be set out by the Minister of Tourism in cooperation with the Minister of Health, are yet to be conferred. The absence of such a regulatory act is the prerequisite for unfair competition, based on the lack of basic criteria for quality and product range of spa and wellness services that everybody should meet, also that might create conditions for misleading information for potential consumers regarding spa and wellness hotel products.

Therefore, Bulgarian hoteliers who want to provide a product able to gain a competitive advantage over competition, as well as promote it successfully on the international market make use of the international voluntary certification systems in the field of spa and wellness tourism. Unfortunately, they are only a few.

Currently the hotels certified by the European Spa Association are: the fivestar Pomorie Grand Hotel in the town of Pomorie, awarded the "Europaspa med" in 2009 , which is in $12^{\text {th }}$ place among the 40 certified hotels in Europe, the four-star Bor Hotel in the town of Velingrad, holding the same "Europaspa med" certificate, and Medi Spa Centre in the Medica Albena Hotel, the resort of Albena.

Despite the abundance of valuable natural resources for practicing spa and wellness tourism and the well-developed specialized hotel super and infrastructure in Bulgaria, the distribution of hotel spa and wellness products is not yet efficient. According to the Strategy for Sustainable Development of Tourism in Bulgaria 2014-2030 statistics the share of balneo-spa and wellness tourism is $6,6 \%$ of all special-interest tourism products and services in Bulgaria. This is a very small share considering the investments made in this industry. There is urgent need for diversifying the channels of distribution by cooperation with tour operators specializing in spa and wellness tourism in Europe, participation in Travel Trade Markets and Fairs specialized in spa and wellness tourism, establishing contacts and relations with organizations and associations for health tourism, health 
insurance and retirement funds with specialized medical and health centres. Offers are to be targeted at concrete market segments - people at an active age, people of the third age, people with overweight problems, etc.

An important indirect distribution channel is the opportunity of hotels to be listed in international voluntary certification systems, hotel marketing consortiums for spa and wellness tourism, as well as cluster formations. All these channels are already established good practices abroad, but not sufficiently applied in Bulgaria yet. All these considerations call for revising the distribution policy of the hotel spa and wellness product in Bulgaria both by state authorities at national and regional level and business professionals.

\section{APPENDIX 1}

Organizations with certification systems for spa and wellness products and services

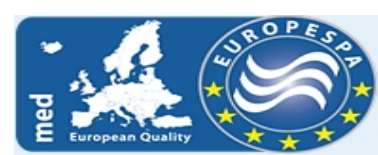

European Spa Association

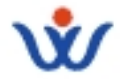

Deutscher Wellness Verband

/German Wellness Union /

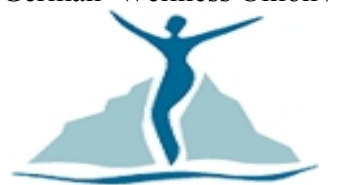

ALPINEWELLNESS

Alpine Wellness Austria

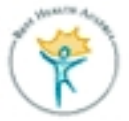

Öst. Gesundheits-Tourismus GmbH

Austrian Public Limited Company for health tourism

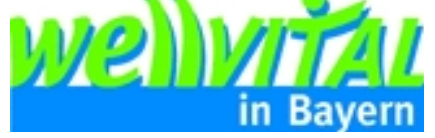

Bayern Tourismus Marketing

$\mathrm{GmbH}$

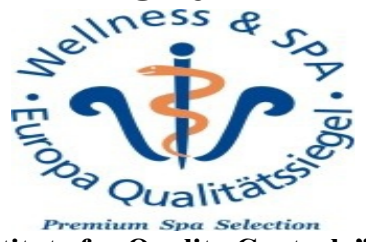

European Institute for Quality Control "Wellness and

\section{Target Groups and Fields of Certification}
Medical Hotels, medical baths, medical and health facilities, and since 2008 medical (health) hotels with spa centres.

Hotels rated more than 3 stars, day spa centres, medical centers, clinics, doctor's surgeries.

Hotels

Hotels and spa and wellness centers

Hotels and spa and wellness centers, facilities and equipment

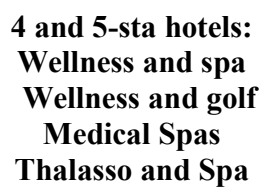




\section{Spa"

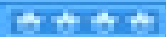 \\ A E LA A

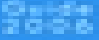

Guide to 2000 spa and wellness hotels with audited quality

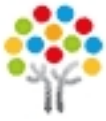

Wellness Hotels of Germany

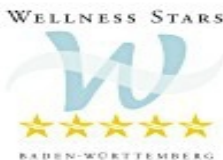

Wellness hotels Province Badenvyurtenberg -

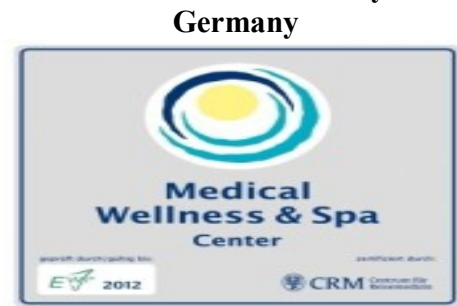

Medical Wellness \& Spa Center in Germany
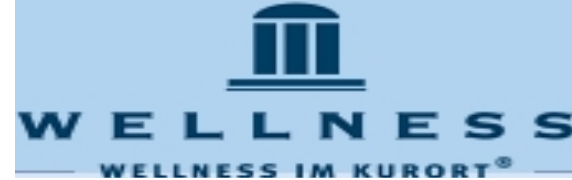

\section{REFERENCES}

1. Berg, W., 2008. Gesundheitstourismus und Wellnesstourismus, Muenchen: Oldenburg Wissenschaftsverlag GmbH.

2. ITB Berlin Convention. 2013. The Global Wellness Tourism Economy [pdf], Available at: <http://www.itbkongress.de/media/itbk/Archiv_2014/ITB_Experts_Forum_Wellness 2/The_Global_Wellness_Tourism_Economy_2013.pdf $>$ [Accessed 19 June 2014].

3. Sacharinov, B., T. Rizova, 2011. Spa Industry Needs Uniqueness. Collection of Articles. Tourism - Challenges in Times of Economic Crisis, Sofia, ed. NBU.

4. Rafailova, G., Sn. Kadieva et al., 2012. Types of Special-Interest Tourism. Science and Economics Publishers. Varna: University of Economics.

5. Spafinder Wellness, Inc. 2014. Top Ten Spa and Wellness Trends Forecast
Available

at: 
$<$ http://www.spafinder.com/trends2014.htm> [Accessed 14 June 2014 ].

6. Meet EVEN Hotels [online] Available at: $<$ http://www.ihg.com/evenhotels/hotels/us/en/reservation $>$ [Accessed 15 March 2015].

7. Luxury Daily, 2013. The Trump Wellness Hotels chain [online] Available at: <http://www.luxurydaily.com/trump-targets-healthconscious-travelers-with-wellness-program $>$ [Accessed 28 February 2015].

8. EuropeSpa med \& wellness GmbH. EuropeSpa certification [online] Available at: <http://europespa.eu/certificates.html $>$ [Accessed 10 March 2015].

9. Investiror.BG, 2014. За 10 години в СПА индустрията у нас са инвестирани 1 млрд. евро [online] Available at: $<$ http://www.investor.bg/ikonomika-i-politika/332/a/sharlopov-za-10godini-v-spa-industriiata-u-nas-sa-investirani-1-mlrd-evro-173221> [Accessed 21 March 2015].

10. Strategy for Sustainable Development of Tourism in Bulgaria 20142030 [online] Available at: http://www.mi.government.bg/bg/themes/nacionalna-strategiya-zaustoichivo-razvitie-na-turizma-v-republika-balgariya-2014-2030-g286-349.html [Accessed 21 March 2015].

Рад је примљен: 22.03.2015.

Прихваћен за објављивање: 26.03.2015.

Received: 22 March 2015

Accepted: 26 March 2015 